\title{
USING COOP-COOP METHOD TO IMPROVE THE STUDENTS' NATURAL SCIENCE LEARNING COMPETENCES
}

\author{
Lila Pangestu Hadiningrum \\ IAIN Surakarta \\ Jalan Pandawa, Dusun IV, Pucangan, Kec. Kartasura, Kab. Sukoharjo, Jawa Tengah \\ Email: lilahadiningrum@gmail.com
}

\begin{abstract}
:
This study aimed at finding out: (1) the extent to which the implementation of emedia (powerpoint learning and macromedia flash) innovations using the coopcoop method improved IPA (natural science) learning competencies especially in mastering the concept of the fifth grade students especially class B; (2) The ways to overcome the obstacles faced in the application of powerpoints and macromedia flash using the coop-coop method. This research used the classroom action method with the steps planning, implementation, observation and reflection (parallel srtucture). Data analysis was an interactive analysis. From the whole cycle that had been done, it could be concluded that: (1) the use of powerpoint and macromedia flash using the coop-coop method improved the students in mastering the concepts of human and animal organs, and green plants materials; (2) constraints of the application of powerpoint and macromedia flash using coop-coop method could be overcome by determining and limiting the material and time.
\end{abstract}

\begin{abstract}
Abstrak:
Penelitian ini bertujuan untuk mengetahui: (1) sejauh mana penerapan inovasi pembelajaran dengan media elektronik (powerpoint dan macromedia flash) menggunakan metode co-coop dapat meningkatkan kompetensi belajar IPA khususnya dalam penguasaan konsep kelas VB Sekolah Dasar (SD), dan (2) cara mengatasi kendala yang dihadapi dalam penerapan powerpoint dan macromedia flash dengan metode co-coop. Penelitian ini menggunakan metode tindakan kelas dengan langkah-langkah menyusun rencana, pelaksanaan atau tindakan, observasi dan refleksi. Analisa data adalah analisis interaktif. Dari keseluruhan siklus yang telah dilakukan dapat disimpulkan bahwa (1) penggunaan powerpoint dan macromedia flash dengan metode co-coop mampu meningkatkan kompetensi belajar IPA khususnya dalam penguasaan konsep anggota tubuh manusia dan hewan, serta bagian pada tumbuhan; dan (2) cara mengatasi kendala dalam penerapan powerpoint dan macromedia flash dengan metode coop-coop dengan pembatasan materi dan waktu.
\end{abstract}

Kata kunci:

Concept of Natural Sciences, Coop-coop Method, Powerpoint, Macromedia Flash

How To Cite: Hadiningrum, L. P. (2019). Using Coop-coop Method to Improve The Students' Natural Science Learning Competences. Lentera Pendidikan : Jurnal Ilmu Tarbiyah dan Keguruan, 22(2), 311-322. 


\section{INTRODUCTION}

Elementary School as the first part of education must provide basic skills and skill strategies since the early classes. Efforts to improve the quality of basic education cannot be delayed anymore especially in improving the quality of the learning process of elementary schools in the revolutionary era 4.0. This is in accordance with the function of basic education, which no longer solely functions as a means of socializing students, but from the beginning must have the potential to grow Indonesian people who will be able to become agents of renewal. The Elementary School function does not merely make its output literate only and has a mass of knowledge that becomes momentary knowledge, in the sense that it is unable to realize its independence, but literacy in the sense of technological literacy and literacy.

Diponegoro Islamic Elementary School is one of the Private Islamic Elementary Schools in Surakarta. Schools always expect the students with low/medium inputs to come out as high outputs. One way to do the above can be done by optimizing learning. Science learning in elementary schools aims to enable students to increase awareness of daily tasks, national pride and freedom and strength and piety to God Almighty, understand the concept of science and its relation and through science students are expected to develop knowledge, abilities, and skills, as well as attitudes and scientific value in solving problems regarding the environment. In the process of learning science, a teacher has an important role in conveying information, training skills and guiding students' learning so that teachers are required to have certain qualifications and competencies, so that the learning and learning process can take place effectively and efficiently. The existence of the right learning method along with achievement motivation will make the students easy to receive and process delivered.

Science teaches various concepts and certain theories requires a specific strategy in learning. If the implementation of learning is right then the students can explain a concept correctly. According to Slavin in Sudarmo (2005: 66) the concept is an abstraction of thought which is a generalization of something specific. With the concept, someone is able to classify things according to his knowledge. Mastery of essential concepts is one of the basic competencies that absolute graduates must have. Criteria for selecting essential concepts, among others, concepts are chosen according to the level of development of children, the concepts chosen should be a prerequisite for learning some advanced concepts, namely the concepts chosen are within the scope of the students' experience.

The level of mastery of concepts that have cognitive dimensions can be measured in various ways, both with written tests, oral tests and deeds tests. Written tests are more appropriate if the number of test takers is relatively large. The results of measurement or evaluation are more objective if all types of written tests, both in the form of subjective and well implemented (Syah, 1985: 154). In this research, the students' assessed through written and oral tests to know the students improvement in understanding Natural Science Learning (IPA) especially to know the concepts of the material of human, animal organs, and green plants. 
Mastery of concepts in students cannot take place simultaneously. Mastery of students' concepts will be different for each student because of several factors. One factor is the initial state or student's input. Winkel (2014: 151) illustrates that: "the initial state, that is, the situation that exists before the learning process begins but can play a role in that". The curriculum objectives include four competencies, namely (1) attitude competence spiritual, (2) social attitudes, (3) knowledge, and (4) skills. Competence is achieved through the intracuricular, co-curriculer, learning process and/or extracurricular. Core competency of knowledge: understanding knowledge factual and conceptual, creature and activities, and objects found at home, at school and playground. Understanding the concept of science and its application in the competency standards of IPA subject for elementary and Madrasah students of Ibtidaiyah are: describe motion devices and its function in animals and humans and how to maintain health human movement, explain respiratory organs and its function in animals and humans, and how to maintain health human respiratory organs, describes the digestive organs and its function in animals and humans and how to maintain health human digestive organs, Explain circulatory organsand its function in animals andhumans and how to maintainhealth of the circulatory organshuman, analyzing inter-relationshipsecosystem components and food webs in the environment, analyzing the effect of heatto changes in temperature andthe form of things in lifedaily, analyzing the water cycle andthe impact on events on earthand the survival of living things, grouping material inside based daily life its constituent components (substancessingle and mixed) ecosystem (Kementerian Pendidikan dan Kebudayaan, 2018: 40-41).

An assessment of the students' progress of IPA learning is carried out during the learning process. Assessment is not only done at the end of the period but is carried out in an integrated (inseparable) manner in the sense that learning progress is assessed from the process, not just the results (products). Science assessments can be done in various ways such as action tests, written tests, observations, questionnaires, attitude scales, portfolios, project results. Thus, the scope of science assessment can be done both on learning outcomes (end of activities) and on the process of obtaining learning outcomes (during learning activities). The results of the assessment can be realized in the form of values with quantitative measurements or in the form of qualitative descriptive comments. In this study the basic competencies to be achieved are students can describe the human body and animal organs (respiratory and digestive organs).

The indicators of achievement of competencies of human and animal organs are to be achieved include: students can identify the structure, functions and processes of the respiratory system in humans and animals, students can identify abnormalities that occur in the respiratory system in humans, students can identify the structure, function and process of the digestive system in humans, students can identify abnormalities that occur in the digestive system of food, students can give examples of technology related to abnormalities that occur in the digestive system of food, 
students can mention the type and content of nutritious foods, students can analyze variations and composition of food consumed during a certain period and arrange a balanced menu for themselves.

This research with the coop-coop method measured the mastery of students' concepts at the beginning, at the end and during the learning process. Based on the input, the school where the research has a medium input, so as to produce high output, continuous improvement of the learning process is needed. The learning process is required to send students with abilities above the complete limit. Changes in complete limits for each subject always change to increase, therefore mastery of the concept of students also needs to be improved, including increasing mastery of the concept of science of materials for human and animal organs and green plants.

To design learning activities that stimulate effective and efficient learning outcomes in each subject matter requires appropriate delivery media. Media (medium) can be interpreted as an intermediary or introduction. Meanwhile, learning media means a vehicle for channeling messages or learning information from communicators (teachers) to communicants (students). Media that attracts attention is not enough, because students are generally interested in learning right then and there, but after learning in the classroom with interesting media is over, students will come back less motivated. Teachers need to develop teaching methods that make students active. The method developed must also consider the state of the student. Powerpoint and macromedia flash are software that is often used by web professionals in displaying multimedia, animation, sound and interactivity. This software is based on vector animation that can produce web animations, presentations, games and films. Powerpoint and macromedia flash in this study are used to present material for human and animal organs. The position of powerpoint and macromedia flash is more than just a program, but it becomes a learning medium that conveys messages in the form of material concepts of human and animal organs delivered by the teacher to students. The media in its delivery requires procedures/ steps chosen to assist students in accepting objects or internalizing content or messages. The procedure or step is called the learning method. So it is clear, in this study the media used are computers, LCDs as display screens and powerpoint and macromedia flash. The method chosen is coop-coop and the message delivered is human and animal organs.

The advantages of powerpoint media are providing convenience in the presentation and selection of macromedia flash based on its advantages over other programs. According to the LPKBM R \& D MADCOMS (2004: 1), the advantages of the macromedia flash program compared to other similar programs include: 1) can make interactive buttons with a movie or other object; 2) can make changes in color transparency in the movie; 3) make changes to animation from one form to another; 4) can make animated movements by following the set path; 5) can be converted and published into several types, including .swf, .html, .gif, .jpg, .png, .exe, .mov. Through several those advantages, it is expected that the message of the material presented will attract students' attention, so that it can improve their mastery of concepts. 
Cooperative learning is a learning model in which students work in small groups to help one another in learning and are valued for their collective achievements (Slavin, 1995: 2) There are several forms of cooperative learning that have been developed including: STAD (Student Teams Achivement Divisions), TGT (Team Game Tournament), Jigsaw, TAI (Team-Assisted Individualization), GI (Group Investigations), LT (Learning Together), Coop- coop.

In this study, the method used is coop-coop. According to Slavin (1995: 119), the coop-coop method is almost the same as the Investigatiaon Group (GI) method when compared to other methods. Both place students in the form of groups to work together with one another discussing a particular topic. Coop-coop invites students to work together in small groups with, the aims are to: 1) increase their understanding of themselves and the world; 2) give an opportunity to share that new understanding with their peers.

In the coop-coop method, although it focuses on capabilities, it can be described as having a strong process orientation. The main concern is not only about the facts or basic skills students get, but also how students develop into humans. The aim is for students to be active in learning so that they will naturally express their curiosity and follow their interests through communication with others. The process orientation is not focused on combining appropriate knowledge, but as a student's personal development facility.

The coop-coop method is simple and flexible. There are several ways to implement it, namely:

\section{Class Discussion}

This activity can be done through early reading, lecturing or giving experiences that can support the learning process. Students are encouraged to express their interest in the lessons to be learned, because coop coop will succeed if students are interested and motivated in learning the material.

\section{Selection of Student Learning Groups and Group Formation}

In coop-coop groups formed are heterogeneous, with a number of 6-7 students per group.

\section{Selection of Group Topics}

The choice of group topics can be done by the students themselves or based on students' interest in the topics of the lesson to be delivered.

\section{Selection of Minitopics}

Each group divides work assignments among members in their respective groups. The division must be based on the level of intelligence, interests and interests of students, so that all students will have a maximum contribution. In this case, the teacher plays roles to: a) invite students to evaluate their group mates; b) give assignments to each student; c) monitor the contribution of each student. If the 
minitopic can be selected correctly, each student will make a unique/different contribution in the group that will support their success.

\section{Minitopic Preparation}

Each student carries out tasks according to his responsibilities, because group success depends on their work. Minitopic preparation includes study in the library, collecting data through interviews or experiments and other student creativity. This minitopic preparation will increase students' interest because the results of their work will be a contribution to their group in sharing.

\section{Minitopic Presentation}

Minitopic presentations in groups must be formal. Each group member is given a special time. During the presentation, members in one group (those who are not presentations) are encouraged to take notes, criticize, encourage, check the appropriate information and those who don't and give feedback. After completing the Minitopic presentation, students reported back to their minitopics after experiencing good improvements through research, feedback and careful thinking.

\section{Preparation of Group Presentations}

Students are encouraged to bring together all the material in the minitopic into a group presentation. Minitopics must be synthesized so that the presentation becomes more interesting. The form of group presentations must follow the synthesis of the minitopic material and in the presentation students can use the blackboard, audio visual media and hand out.

\section{Group Presentations}

During the presentation the group's presentation took over class control. Group members are responsible for how time, space and learning resources in the classroom are used. Students are encouraged to make full use of class facilities. If the group has difficulty managing time, then the teacher can help limit the time for each group.

\section{Evaluation}

There are three types of evaluations that can be done, namely: a) evaluation of group presentations by class; b) evaluate individual contributions to the group through their group mates; c) evaluation of the results of each individual's understanding of the minitopic presentation by the teacher. Through each presentation, the teacher directs group discussions on the content and format of the presentation. The step of the research carried out is more or less like the explanation above.

Several studies related to the cooperative method had been conducted. One of them was Daniel (2012) who was investigated the influence of gender on Junior Secondary students' academic achievement in basic science using cooperative learning teaching strategy. Total number of one hundred and twenty (120) students 
obtained from the intact classes of the three selected Junior Secondary Schools in the three selected Local Government Areas of Ogun State, South-west Nigeria, participated in the study. This study employed a quasi-experimental design. The instruments used of this study were lesson note and test. Descriptive and independent samples t-test statistics were used to analyzed the data. The results indicated that academic achievement of male and female students at the pretest, posttest, and delayed posttest had no significance differences. Similar research has been carried out by (Zaid Bataineh, 2015: 217) who concluded that both cooperative learning methods in control and experimental groups (coop-coop and Think-PairShare, respectively) had no significant difference. Inaddition, Christian \& Pepple (2012) investigated the effects of cooperative and individualized learning strategies on students'achievement in chemistry in Rivers State. There were 370 Senior Secondary II students from six public secondary schools involved as the sample of this study. The $3 \times 2 \times 2$ factorial pretest-posttest quasi-experimentaland control design was adopted for this study. Mean, standard deviation, linear regression, ANCOVA and Scheffe Multiple Comparisons were used for data analysis. The results of the tests showed statistically significant effect of learning strategies in chemistr. The finding also showed a very weak and significant effect of the combination of all the predictor variables onstudents' achievement. However, relatively the effect of the individual predictor variables on students' achievement inchemistry was found to describe the following trend: age<gender<learning strategies with learning strategies and genderhaving significant relative effect students' achievement.

Based on the observations, the major students' problem in natural science subject (IPA) are low achievement motivation and affect the low competencies of learning. To create an atmosphere so that students are more active learning requires the willingness and ability of teachers to make the right decisions with the learning situation created and consider the teaching conditions predicted to affect the achievement of learning competencies. In addition, a method is pursued that leads to the development of logical thinking, critical attitude and sensitivity of students to their own environment to the widest.

The media that most easily attracts students' attention is visual media. Technological developments have caused the visual media to be used not only in pictures or charts, but can use computers in the manufacturing process, so that the packaging is more attractive. Examples of the use of these media are presentations that use the Powerpoint and macromedia flash programs. The results of the interview indicated that during the process of learning science at Diponegoro Islamic Elementary School it was still rare to use visual media even though in the form of presentations, while in the school there were supporting facilities such as computers, laptops, LCDs and televisions.

One method that can make students active in the Co-op Co-op method that is included in the Cooperative Learning approach. The use of media and learning methods basically aims to improve quality learning, so in the end there is optimal 
mastery of concepts by students. Increased mastery of the concept is expected to increase school output, so that private schools with low input can produce high output and the community does not dominate private schools. Based on the identification of these problems, the researcher took the title efforts to increase mastery of the concept of IPA (saving material of human or animal organs and green plants) through powerpoint and macromedia flash learning innovations with the coop-coop method (class action research in VB class students in Islamic Primary Schools Diponegoro, Pasar Kliwon Surakarta). This study aims to find out: (1) the extent to which the application of powerpoint learning and macromedia flash innovations using the co-coop method can improve science learning competencies especially in mastering the concept of VB Elementary School classes; (2) constraints and ways to overcome the obstacles faced in the application of powerpoints and macromedia flash using the co-coop method.

\section{RESEARCH METHOD}

This research used Classroom Action Research (CAR) with the steps planning, implementation, observation and reflection (parallel srtucture). The research was conducted in B class students of the fifth grade at Diponegoro Islamic Primary School, Pasar Kliwon Surakarta. This study used coop-coop method through powerpoint and macromedia flash in teaching material of human organs and animals. In applying the method, the researchers used repetitive/cycle actions in each learning. Based on the objectives of this study, this research was an explanation of the facts and circumstances.

In collecting the data, researchers needed data collection tools called research instruments. Data were then collected through observation list/sheet, Interview, document review, and test. The instruments were prepared by the researchers to find out data related to: 1) the students' satisfaction with the use of powerpoint and macromedia flash; 2) the students' assessment of learning using the co-coop method; 3) the students' assessment of the performance of group mates; 4) the assessment of processes and test of learning outcomes (Sahin, 2010).

The test instruments as learning outcomes at the end of the learning (evaluation) were made by the researchers to determine the increase of the students' concept mastery (cognitive domain). While assessing the process was done through discussion group portfolio (cognitive domain) and observation of group presentations (Psychomotor). In the early stages before the learning begun, an initial ability test of instrument (cognitive domain) was also needed.

Procedures and steps in carrying out actions followed a model developed by Wiratmadja (2006: 66) called spiral model. Activities were conducted through plan, action, observation, reflection and revision with modification as a further step of improvement. These stages were described as follows: 


\section{Preparation Stage}

At this stage, the activities carried out were observing and identifying problems in IPA learning and preparing Powerpoint media and macromedia flash which was used by researchers as natural science teachers. In this study, macromedia flash and Powerpoint from the Indonesian Educational Animation VCD for Elementary School were used by the researchers.

\section{Planning Stage}

In the first cycle, researchers compiled several research instruments to be used, while in the next cycle researchers planned changes in learning in accordance with the objectives and results of reflection.

Implementation Stage/action

The activity done in the implementation phase of action was the use of Powerpoint and macromedia flash in the Coop-coop method.

\section{Observation Stage}

Observation was done from the beginning. To found out the results of these observations, researchers interviewed the students to know their satisfaction with the use of Powerpoint and macromedia flash using Coop-coop method, while the goal of increasing mastery of concepts was observed through the researchers' evaluation at the end of each cycle as a form of individual assessment in the domain cognitive. The researchers also evaluated the students through group performances in the presentation in front of the class as a form of group assessment which was then included in the assessment of the Psychomotor domain. Interviews with students regarding the performance of their group mates were also conducted to assess the role of students in the group.

\section{Reflection Stage}

At this stage, the researcher evaluated the evaluation results. Through this stage, the researchers measured the learning successful. Whether there was an increase in mastery of concepts or not, and whether the students felt happy and interested in Powerpoint and macromedia flash using Coop-coop method. If it had not provided optimal results and was not in line with the expectations of the researchers, then the action was corrected in the next cycle. The data obtained was became the reflection material for the researchers to improve learning by emphasizing the weaknesses of previous learning.

\section{Follow Up Stage}

After this research activity, it was expected that there would be a follow up from the natural science teacher of the school to make continuous improvements and to develop learning activities. 


\section{RESULTS AND DISCUSSION}

The results of the research and monitoring were described from the development of the students' mastery of concepts after applying Powerpoint and macromedia flash using the coop-coop method, as well as mastery of students' natural science concepts in each evaluation at the end of the lesson as listed in the graph below.

Table 1: The Analysis Results of The Students' Mastery of Science Concepts Before Treatment, Cycle I and Cycle II and The Means After Treatment of Class VB

\begin{tabular}{lrrrrrr}
\hline & N & Minimum & Maximum & Sum & Mean & $\begin{array}{c}\text { Std. } \\
\text { Deviation }\end{array}$ \\
\hline Before trreatment & 33 & 50 & 70 & 2060 & 62.42 & 6.746 \\
\hline Cycle I & 33 & 60 & 95 & 2530 & 76.67 & 9.974 \\
\hline Cycle II & 33 & 70 & 100 & 2865 & 86.82 & 9.085 \\
\hline After treatment & 33 & 60 & 88 & 2486 & 75.33 & 7.144 \\
\hline
\end{tabular}

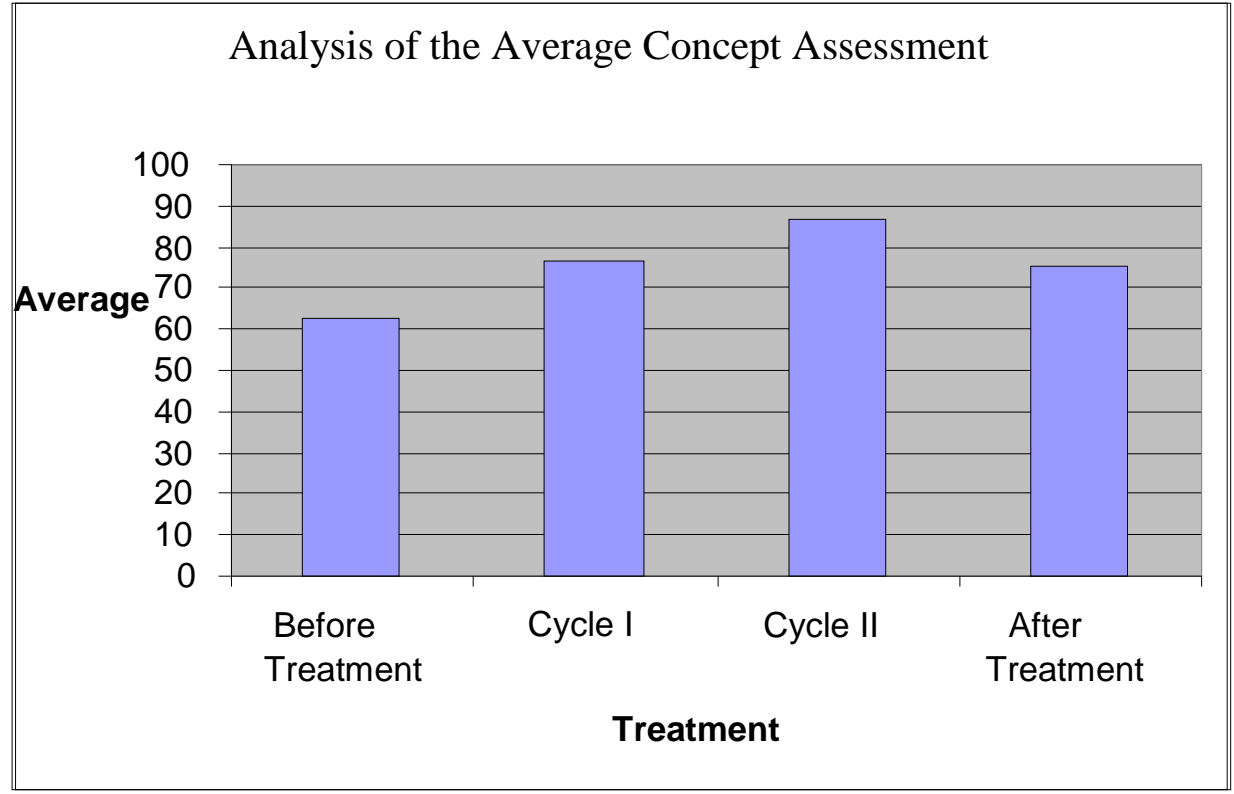

Figure 1: Histogram Means of The Students' Mastery of Natural Science Concept Before Treatment, Cycle I, Cycle II, and Average After Treatment of Class VB

Table 2: Analysis of Affective and Psychomotor Assessment of Cycle I and II

\begin{tabular}{cccc}
\hline Team & Observation Cycle I & Observation Cycle II & Category \\
\hline I & 70 & 80 & Good \\
II & 75 & 80 & Good \\
III & 70 & 76 & Good \\
IV & 80 & 85 & Good \\
V & 80 & 85 & Good \\
VI & 75 & 75 & Good \\
\hline Average & 75 & 80 & Good \\
\hline
\end{tabular}


The mastery improvement of the concepts was measured by increasing the results of cognitive domain evaluations. The concepts achieved by the students had been determined by the researchers based on basic competencies.

The tables and graph above showed the results of actions in each cycle. In the first to the second cycles of the implementation of powerpoint and macromedia flash using coop-coop method, the students'score had improvement. The students achieved better scores so that the mastery of concepts on average from 62.42 increased to 76.67. It indicated that the first cycle in groups using Powerpoint and macromedia flash using the coop-coop method on natural science (IPA) learning results were quite good. Moreover, the researchers wanted to improve by resolving the deficiencies in cycle II.

The mastery of natural science (IPA subject) learning concept before applying Powerpoint and macromedia flash using the coop-coop method was low. The development in the first cycle described the increase of the students' concept. The students' concept scores after applying powerpoint and macromedia flash using the coop-coop method in the first cycle improved than the previous scores. After observations and reflection activities, the constraints in applying powerpoint and macromedia flash using the coop-coop found were the students were not fully involved in group discussions and presentations. Based on the results of analysis and reflection, the researchers in teaching and learning process through an action plan wanted to involve all the students with their guidance. Then, the action plan were modified with practice so that the students could learn directly in real life. To overcome the learning obstacles, it needed more preparation, time, and energy.

From the whole cycle that had been done, it could be concluded that the use of Powerpoint and macromedia flash using coop-coop method improved the students' concept in learning IPA. In each learning cycle, the researchers tried to overcome the obstacles faced by the students so that the teaching and learning process run effectively and efficiently.

\section{CONCLUSION}

The result of this research indicated that the implementation of powerpoint and macromedia flash using the coop-coop method improved the students' mastery concepts of human, animal organs, and green plants materials. In addititon, the constraints of the implementation of powerpoint and macromedia flash using coopcoop method could be overcome by determining and limiting the material and time.

Theoretical implications of this study could be used to: improve and expand the horizons of knowledge for readers, support existing theories in future studies as one of the reference sources for other researchers who want to conduct further research on this issue. Practical implications of this study could be practically applied to IPA learning at Diponegoro Elementary School to increase the students' biological concepts. 


\section{REFERENCES}

Christian, \& Pepple. (2012). Cooperative and Individualized Learning Strategies as Predictors of Students' Achievement in secondary School Chemistry in Rivers State. Vocational Education and Technology, 9(2). Retrieved from https:// pdfs.semanticscholar.org/7734/5c19e275a7483893b359489a99a2a0207ba3.pdf

Daniel, O. (2012). Gender Difference in Nigerian Junior Secondary Students' Academic Achievement in Basic Science. Educational and Social Research, 2(1). Retrieved from https://www.mcser.org/images/stories/Jesrjournal/ January_2012/oludipe daniel i.pdf

Departemen Penelitian dan Pengembangan MAD COMS. (2004). Makromedia Flash MX. Yogyakarta: Andi.

Kementerian Pendidikan dan Kebudayaan. (2018). Peraturan Menteri Pendidikan dan Kebudayaan Republik Indonesia Nomor 37 Tahun 2018.tentang Perubahan Atas Peraturan Menteri Pendidikan Dan Kebudayaan Nomor 24 Tahun 2016 Tentang Kompetensi Inti dan Kompetensi Dasar Pelajaran Pada Kurikulum 2013

Sahin, A. (2010). Effects of Jigsaw II Technique on Academic Achievement and Attitudes to Written Expression Course. Educational Research and Reviews, 5(12), 777-787. Retrieved from https://www.researchgate.net/publication/ 228346703_Effects_of_Jigsaw_II_technique_on_academic_achievement_and_ attitudes_to_written_expression_course

Slavin. (1995). An Introduction to Cooperative Learning Research dalam Robert E. Slavin, dkk. London: Plenum Press.

Sudarmo, U. (2005). Miskonsepsi dalam Konsep Kesetimbangan Kimia pada Siswa dan Guru di SMA Kota Surakarta. Surakarta: Program PascaSarjana UNS.

Syah, M. (1985). Learning to Cooperate, Cooperating to Learn. New York and London: Plenum Press.

Winkel, W. (2014). Psikologi Pengajaran. Yogyakarta: Media Abadi.

Wiratmadja, R. (2006). Metodologi Penelitian Tindakan Kelas. Bandung: Program Pascasarjana UPI \& Remaja Rosdakarya.

Zaid Bataineh, M. (2015). Think-Pair-Share, Coop-coop and Traditional Learning Strategies on Undergraduate Academic Performance. Educational and Social Research MCSER Publishing, 5(1). Retrieved from https://www. researchgate.net/publication/271038328_Think-Pair-Share_Co_Op-Co_Op_ and_Traditional_Learning_Strategies_on_Undergraduate_Academic_Performan ce 